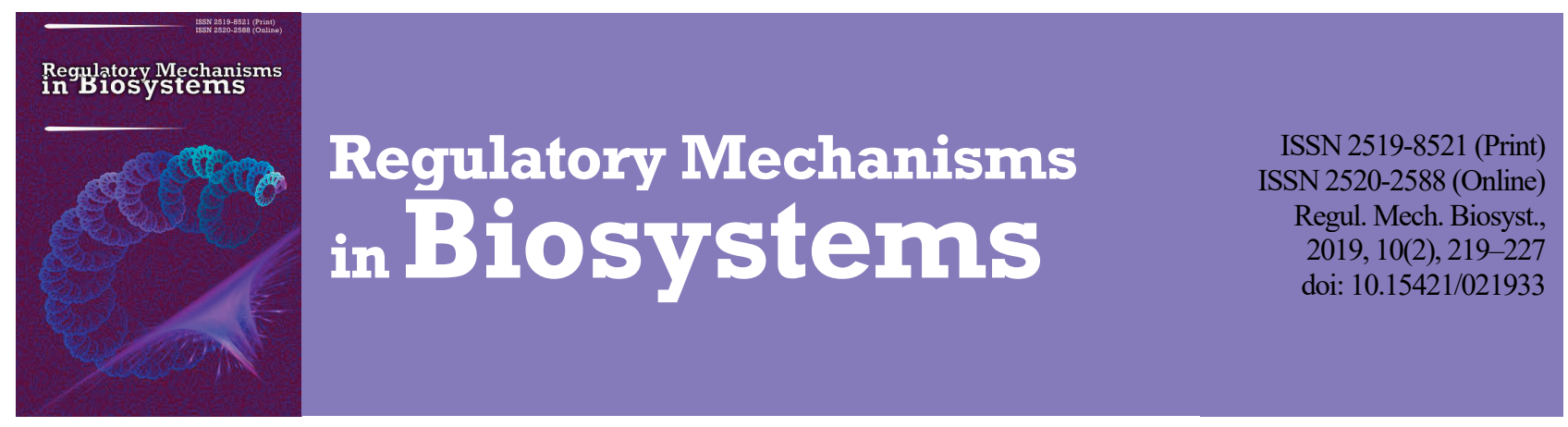

\title{
Interdependence of oxidative/antioxidant system indicators and thyroid status under conditions of prolonged exposure to small doses of radiation
}

\author{
V. L. Sokolenko, S. V. Sokolenko \\ Bohdan Khmelnytsky National University of Cherkasy, Chercasy, Ukraine
}

Article info

Received 02.04.2019

Received in revised form 30.04.2019

Accepted 03.05.2019

Bohdan Khmelnytsky National University of Cherkasy,

Shevchenko st., 81,

Chercasy, 18031, Ukraine.

Tel.: +38-067-869-17-91.

E-mail:sokolenko@ukr.net

\begin{abstract}
Sokolenko, V. L., \& Sokolenko, S. V. (2019). Interdependence of oxidative/antioxidant system indicators and thyroid status under conditions of prolonged exposure to small doses of radiation. Regulatory Mechanisms in Biosystems, 10(2), 219-227. doi:10.15421/021933
\end{abstract}

We have studied the interdependence of the intensity of oxidative processes/antioxidant level and the thyroid status parameters in a group of students aged 18-24 who lived for a long time in the territory of enhanced radioecological control (density of soil contamination by isotopes $\left({ }^{137} \mathrm{Cs} 3.7 \cdot 10^{4}-18.5 \cdot 10^{4} \mathrm{~Bq} / \mathrm{m}^{2}\right)$. We examined 50 people from relatively environmentally friendly areas (control group) and 50 people from IV radiation zone (experimental group). In the experimental group, there were no individuals with clinical manifestations of thyroid pathology. However, subgroups with signs of hyperthyroidism and hypothyroidism were identified. We evaluated the level of cortisol, thyrotrophic hormone (TSH), triiodothyronine $\left(\mathrm{T}_{3}\right)$, thyroxine $\left(\mathrm{T}_{4}\right)$, malonic dialdehyde (MDA), ceruloplasmin (CP), transferrin (Tf), sulfhydryl groups (SH); we calculated the oxidative stress index (OSI). The research was conducted one month before the examination time and also during the exams as a factor in increased emotional stress. A lowered CP level was found in the subgroup with signs of hypothyroidism; SH groups - in all subgroups, separated by thyroid status. The oxidative stress index was higher in all students examined of the experimental group, compared with the control. The growth of MDA level is marked in the experimental group - it is the most strongly pronounced in conditions of additional emotional load in people with signs of hyperthyroidism and hypothyroidism. CP level significantly decreased in the subgroup of hyperthyroidism on the background of $\mathrm{T}_{3}$ decrease. OSI increased in all students examined from the experimental group. In the subgroup of hypothyroidism it became significantly higher than in the subgroup of euthyroidism. A positive correlation between the levels of $\mathrm{CP}$ and $\mathrm{T}_{3}$ was found. The highest values of the correlation coefficients were noted for subgroups with signs of hyperthyroidism and hypothyroidism, with the coefficient significance increasing under conditions of emotional stress. The index of oxidative stress in the experimental group positively correlated with the level of TSH - in terms of emotional stress, the statistical significance of the coefficients disappeared. In the subgroups divided by thyroid status, variability of interactions between OSI and $\mathrm{T}_{3}$ was observed but it was not statistically significant. It was found that the participation of thyroid status in supporting redox homeostasis in people aged 18-24 who suffered from chronic small-doze radiation exposure was realized mainly by the influence on the antioxidant system. The ability of thyroid hormones to maintain a proper antioxidant state was suppressed in this group. The unbalanced relationship between thyroid hormones and oxidative stress indicators is strongly manifested under conditions of additional emotional stress.

Keywords: Chornobyl disaster; malonic dialdehyde; ceruloplasmin; thyroid-stimulating hormone; triiodothyronine; emotional stress

\section{Introduction}

The activity of hormones of the thyroid gland (thyroid hormones, TG) is an important factor in determining the life span of an organism. They are responsible for growth, metabolic rate and energy consumption, take part in the work of the brain, musculoskeletal system and cardiovascular system. The specifics of thyroid hormone metabolism can contribute to adaptation to various environmental problems (Garasto et al., 2017). Thyroid hormones affect the energy metabolism, accelerating energy metabolism stimulates the development of reactive oxygen species (ROS) in target tissues, which results in higher consumption of cellular antioxidants and inactivation of enzymatic mechanisms that provide antioxidant protection, causing oxidative stress (Videla, 2000). Thyroid hormones regulate the synthesis and degradation of proteins, vitamins and antioxidant enzymes, play an important role in the production of free radicals. Changes in level of thyroid hormones are believed to be one of the main physiological modulators of cellular oxidative stress in vivo (Campos \& Casado, 2015), and this is done by stimulating several enzyme systems (De Vito et al., 2012). Active forms of oxygen play an important role in physiological processes. However, oxidative damage to molecules occurs simultaneously. In physiological conditions, products and detoxification of ROS are more or less balanced. In the thyroid gland which produces thyroid hormones, ROS and free radicals are involved in both physiological and pathological processes. In particular, hydrogen peroxide $\left(\mathrm{H}_{2} \mathrm{O}_{2}\right)$ is crucial for the biosynthesis of thyroid gland hormones, acting at different stages of the process. The involvement of active forms of oxygen in the pathologies of the thyroid gland depends, to a large extent, on the presence and effectiveness of antioxidants (Karbownik \& Lewinski, 2003). Oxidative stress mutually correlates with hormonal disorders, being connected with both hyperthyroidism and hypothyroidism. In some cases, oxidative stress is not a manifestation of the adaptation process, but is subject to thyroid dysfunctions, in particular, autoimmune thyroid diseases (Baser et al., 2015; Mancini et al., 2016).

It is known that ionizing radiation affects both the thyroid and oxidative-antioxidant status of the organism. It was the thyroid system that turned out to be the most sensitive to the results of the Chornobyl accident with early observed effects (Popovych et al., 2003). The risk of development of thyroid gland pathologies is considered to be high enough both by scientists and doctors, despite the long time that has 
passed since the radiation catastrophe, it concerns both acute and chronic exposure (Cardis \& Hatch, 2011; Takamura et al., 2016; Boice, 2017; Rumiantsev et al., 2017). A special risk group is the people who were $0-5$ at the time of the accident, which indicates the high vulnerability of this age group to radiation exposure. Recent data indicates the possibility of remote thyroid abnormalities, as a consequence of longterm low-dose radiation, in the absence of direct exposure to radioactive iodine (Abou-El-Ardat et al., 2012; Fushiki, 2013; Takamura et al., 2016). Often they are combined with increased anxiety: a typical sign of a stressful situation (Contis \& Foley, 2015).

Activation of oxidative processes under conditions of ionizing radiation is determined by its stressful effect (Nylund et al., 2014) and the formation of radiolysis products with high oxidation or reducing activity (Kam \& Banati, 2013). Radiation-induced oxidative processes are clearly manifested in acute irradiation (Combs \& Combs, 1986), however, the effects of small doses are rather ambiguous and obviously depend on certain additional factors (Stone \& Dratz, 1982).

Low-dose ionizing radiation (LDIR) is a type of low-frequency chronic radiation that does not cause significant toxic effects. However, it can accelerate cellular ageing by increasing the activity of ROS and destroying biopolymers (Loseva et al., 2014). However, views on the expressed damaging effect of small doses due to oxidative processes are quite contradictory. Some authors point out certain theoretical calculations and the lack of precise dosimetry and question the presence and negative effects of increased oxidative stress by LDIR exposure (Smith et al., 2012). Others argue that, in general, there is a significant influence of low doses of ionizing radiation on the oxidative status of the organism (Einor et al., 2016).

Obviously, an important substrate for oxidative processes with ionizing radiation is lipids (Dostert et al., 1991), and the lipid profile is closely related to the thyroid status of the organism (Mustafina et al., 2010; Kannisto et al., 2014; Lindemann et al., 2014; Sinha et al., 2014).

Currently, a significant part of the territory of Ukraine is contaminated with ${ }^{137} \mathrm{Cs}$ isotope, and the variability of radionuclide activity within the radiation zone IV is quite significant (Sokolenko \& Sokolenko, 2015). We have shown that the inhabitants of the territory of enhanced radioecological control demonstrated a certain tension of the thyroid system, which was characterized by high TSH concentration in people with a high $\mathrm{T}_{3}$ level in peripheral blood. The thyroid status correlated with lipid parameters (Sokolenko \& Sokolenko, 2017). Also, in this cohort radiation-induced intensification of oxidative processes was detected, which grew under conditions of additional stress of emotional nature and influenced the immune system (Sokolenko et al., 2018).

The objective of this work was determining the specifics of the interrelation between the thyroid and oxidative-antioxidant systems in people aged 18-24 who lived for a long time in radiation-polluted territories, in the conditions of absence/presence of additional psychoemotional load.

\section{Materials and methods}

We have examined 50 students from the radiation free regions of Cherkasy region (control group) and 50 students who came to the Bohdan Khmelnytsky National University of Cherkasy from the territories of the intensified radioecological control area (IV zone with a soil pollution density above the pre-accident level $\left({ }^{137} \mathrm{Cs} 3.7 \cdot 10^{4}-18.5 \cdot 10^{4}\right.$ $\left.\mathrm{Bq} / \mathrm{m}^{2}\left(1-5 \mathrm{Ku} / \mathrm{km}^{2}\right)\right)$. The age of the examined students was $18-24$ years. In the experimental group there were no persons with clinical manifestations of thyroid gland pathology.

Blood samples were taken in the morning, before eating, by medical specialists of the student sanatorium Edem, affiliated to the University, and of the clinical diagnostical laboratory of the communal non-commercial organization Cherkasy First City Hospital. The analyses were performed in the laboratories of the Bohdan Khmelnytsky National University of Cherkasy. In conducting the research, the bioethical principles of medicalbiological research with human participation were observed in accordance with the Helsinki Declaration (Ethical Principles Regarding Human Experimentation). The examined students gave written consent to participate in research and to publication of the results.
The first blood sample was taken a month before the winter examination session, the second (to assess the effect of additional emotional load) - after the first exam.

The criterion for stress was the level of cortisol in serum (evaluated using the BIO-RAD (USA) kit).

The thyroid status was assessed by presence in blood serum of the thyroid stimulating hormone (TSH) (using TSH-RIA test kits (Immunotech, Czech Republic), thyroxine $\left(\mathrm{T}_{4}\right)$, and triiodothyronine $\left(\mathrm{T}_{3}\right)$ (using the RIO-T4-IPR test kits and RIO-T3-IPR of the Institute of Bioorganic Chemistry of the National Academy of Sciences of the Republic of Belarus).

Indicators of lipid peroxidation (level of malondialdehyde (MDA)) and antioxidant system (levels of ceruloplasmin (CP), transferrin (Tf) and sulfhydryl groups (SH-groups)) were determined according to the method proposed by Korol \& Myhal (2012). According to the same methodology, the index of oxidative stress was calculated (Korol \& Myhal, 2012). The calculation process is described in detail in our previous article (Sokolenko et al., 2018).

By the level of triiodothyronine $\left(\mathrm{T}_{3}\right)$ within the experimental group, three subgroups were separated: with the signs of euthyroidism (15 people); with signs of hyperthyroidism ( 24 persons); and with signs of hypothyroidism (11 people).

The data in the tables are presented as mean \pm standard error $(\mathrm{x} \pm$ $\mathrm{SE}$ ). Data were compared using the ANOVA method. The interconnections between the parameters were analyzed by determining the Pearson correlation coefficient. The statistical significance of the difference between the groups and the significance of the correlation coefficient are indicated by three levels: $\mathrm{P}<0.05, \mathrm{P}<0.01$ and $\mathrm{P}<0.001$.

\section{Results}

It was determined that among the 50 people aged 18-24 who lived for a long time in the territory of enhanced radioecological control and were tested, the thyroid status parameters coincided with those obtained for a larger group and described earlier: in the hypothyroidism subgroup $\mathrm{T}_{3}$ exceeded the lower level of referential meaning, in the group of hyperthyroidism - it tended to approach to the upper limit. Clinical signs of thyroid pathology were not marked among those examined. An important sign was the elevated level of thyroid stimulating hormone in the subgroup of hyperthyroidism, which is not typical for this thyroid status (Table 1). In all three subgroups of the experimental group, separated by thyroid status, there was a tendency to increase in the level of malonic dialdehyde compared to control. However, the increase was not statistically significant (Table 1).

Ceruloplasmin level was statistically significantly lowered, compared with control, in the subgroup of hypothyroidism; the level of sulfhydryl compounds was lowered in all three subgroups of the experimental group, divided by the thyroid status. Moreover, in the subgroups of hyperthyroidism and hypothyroidism, the content of sulfhydryl compounds was lower than in the subgroup of euthyroidism. Transferrin level showed a downward trend in all three subgroups, which was not statistically significant. The index of oxidative stress was statistically significantly higher in all subgroups of the experimental group, compared with the control (Table 1).

Under conditions of additional psychoemotional load, MDA level significantly increased in all three subgroups, in the hyperthyroidism and hypothyroidism groups MDA score was significantly higher not only compared with pre-exam values but also with MDA level in control (in terms of emotional load) and in the experimental group of euthyroidism (Table 1). The level of ceruloplasmin significantly decreased in comparison with pre-exam values in the hyperthyroidism subgroup and became lower than the control under the same conditions. In the hypothyroidism subgroup, the level of ceruloplasmin remained lower, compared with control and, despite the lack of a significant decrease compared to preexam values, it was lower than the index in the euthyroidism subgroup (Table 1).

Transferin did not show statistically significant changes under conditions of psycho-emotional load. The level of sulfhydryl groups significantly increased both in control and in all experimental subgroups. However, in experimental subgroups, it remained statistically signifi- 
cantly lower compared to control, and in the subgroups of hyperthyroidism and hypothyroidism lower compared to the euthyroidism subgroup (Table 1). Oxidative stress index did not change in control and significantly increased in the subgroups. In the subgroup of hypothyroidism, it became significantly higher than in the euthyroidism subgroup (Table 1).

Table 1

Cortisol, thyroid status, oxidative processes and antioxidant system parameters in the control and experimental groups (upper line - before emotional stress, lower line - during emotional stress)

\begin{tabular}{|c|c|c|c|c|}
\hline \multirow{2}{*}{ Components } & \multirow{2}{*}{$\begin{array}{l}\text { Control, } \mathrm{x} \pm \mathrm{SE} \\
(\mathrm{n}=50)\end{array}$} & \multicolumn{3}{|c|}{ Experimental group: people undergoing the prolonged influence of small radiation doses, $x \pm S E(n=50)$} \\
\hline & & euthyroidism $(\mathrm{n}=15)$ & hyperthyroidism $(\mathrm{n}=24)$ & hypothyroidism $(\mathrm{n}=11)$ \\
\hline \multirow{2}{*}{ Cortisol, nmol/1 } & $351.1 \pm 10.1$ & $630.0 \pm 21.1 * * *$ & $633.8 \pm 19.0^{* * *}$ & $625.0 \pm 17.4^{* * *}$ \\
\hline & $801.3 \pm 12.5^{\$ \$ \$}$ & $880.5 \pm 18.4^{* * * \$ \$ \$}$ & $890.8 \pm 20.1 * * * \$ \$ \$$ & $879.4 \pm 22.3^{* * \$ \$ \$}$ \\
\hline \multirow{2}{*}{$\begin{array}{l}\text { Thyroid-stimulating hormone (TSH), } \\
\mu \mathrm{U} / \mathrm{mL}\end{array}$} & $2.31 \pm 0.21$ & $3.07 \pm 0.43$ & $3.70 \pm 0.30 * * *$ & $3.75 \pm 0.30^{* * *}$ \\
\hline & $2.32 \pm 0.35$ & $2.42 \pm 0.30$ & $2.75 \pm 0.50$ & $2.79 \pm 0.51$ \\
\hline \multirow{2}{*}{ Triiodothyronine $\left(\mathrm{T}_{3}\right), \mathrm{nmol} / \mathrm{L}$} & $1.54 \pm 0.06$ & $1.55 \pm 0.05$ & $2.61 \pm 0.08 * * * \ldots$ & $0.77 \pm 0.04 * * * \ldots \#$ \\
\hline & $1.41 \pm 0.06$ & $1.44 \pm 0.05$ & $1.70 \pm 0.08^{* * \$ \$ \$ \$ \#}$ & $0.74 \pm 0.05 * * * \ldots$ \\
\hline \multirow{2}{*}{ Thyroxine $\left(\mathrm{T}_{4}\right), \mathrm{nmol} / \mathrm{L}$} & $81.6 \pm 5.7$ & $96.0 \pm 7.3$ & $129.1 \pm 8.1 * * * \#$ & $79.0 \pm 9.1$ \\
\hline & $76.8 \pm 9.1$ & $94.0 \pm 9.1$ & $123.2 \pm 9.2^{* * * \#}$ & $78.1 \pm 7.2$ \\
\hline \multirow{2}{*}{ Malondialdehyde (MDA), $\mathrm{mmol} / \mathrm{L}$} & $125.4 \pm 27.5$ & $130.1 \pm 9.1$ & $143.1 \pm 8.4$ & $140.3 \pm 9.7$ \\
\hline & $150.8 \pm 36.4$ & $165.1 \pm 10.1^{\$}$ & $228.6 \pm 6.1 * \$ \$ \$ \#$ & $234.6 \pm 5.3 * \$ \$ \$$ \\
\hline \multirow{2}{*}{ Ceruloplasmin (CP), g/L } & $0.24 \pm 0.02$ & $0.22 \pm 0.01$ & $0.25 \pm 0.01$ & $0.18 \pm 0.02 *$ \\
\hline & $0.27 \pm 0.03$ & $0.23 \pm 0.02$ & $0.19 \pm 0.02 * \$$ & $0.17 \pm 0.01 * * \#$ \\
\hline \multirow{2}{*}{ Transferrin (Tf), cond. un. } & $5.33 \pm 1.01$ & $4.55 \pm 0.65$ & $4.32 \pm 0.80$ & $4.21 \pm 0.61$ \\
\hline & $5.50 \pm 1.02$ & $4.59 \pm 0.97$ & $4.25 \pm 0.88$ & $3.99 \pm 0.71$ \\
\hline \multirow{2}{*}{ SH-groups, $\mathrm{mmol} / \mathrm{L}$} & $2.52 \pm 0.03$ & $1.85 \pm 0.04 * * *$ & $1.66 \pm 0.04 * * * \#$ & $1.59 \pm 0.03 * * * \ldots \#$ \\
\hline & $2.73 \pm 0.07^{\$ \$}$ & $2.22 \pm 0.06^{* * * \$ \$ \$ \$}$ & $1.99 \pm 0.05^{* * * \$ \$ \$ \# \# ~}$ & $1.87 \pm 0.05^{* * *} \$ \$ \$ \$ \#$ \\
\hline \multirow{2}{*}{ Oxidative stress index (OSI), un. } & $1.03 \pm 0.04$ & $1.37 \pm 0.04 * * *$ & $1.40 \pm 0.04^{* * *}$ & $1.46 \pm 0.04^{* * *}$ \\
\hline & $1.10 \pm 0.05$ & $1.87 \pm 0.04 * * * \$ \$ \$$ & $1.98 \pm 0.04 * * * \$ \$ \$$ & $2.06 \pm 0.03 * * * \$ \$ \$ \$ \#$ \\
\hline
\end{tabular}

Notes: ${ }^{*}-\mathrm{P}<0.05,{ }^{*}-\mathrm{P}<0.01, * * *-\mathrm{P}<0.001$ compared to control; ${ }^{\$}-\mathrm{P}<0.05,{ }^{\$}-\mathrm{P}<0.01,{ }^{\$ \$ \$}-\mathrm{P}<0.001$ compared to the coefficient before psycho-emotional load; ${ }^{\#}-\mathrm{P}<0.05,{ }^{\#}-\mathrm{P}<0.01,{ }^{\#}-\mathrm{P}<0.001$ compared to the coefficient in euthyroidism subgroup.

Correlation analysis revealed a lack of statistically significant bonds between the oxidation/antioxidant system and thyroid status parameters in the control group. To moderate expressed bonds we can refer the positive correlation between thyroid stimulating hormone and malonic dialdehyde $(r=0.21$ without emotional stress, $r=0.24$ during emotional load; $\mathrm{P}>0.05)$; triiodothyronine and ceruloplasmin $(\mathrm{r}=0.25$ without emotional load, $\mathrm{r}=0.27$ during emotional load; $\mathrm{P}>0.05)$; and negative correlation: between the level of triiodothyronine and the index of oxidative stress $(r=-0.19$ without emotional load, $r=-0.21$ during emotional load; $\mathrm{P}>0.05$ ). In the experimental group, the absence of statistically significant bonds of the oxidation-antioxidant system and thyroid status parameters are observed for MDA, transferrin and SH-groups levels (Fig. 1-9). Ceruloplasmin positively correlated with the level of triiodothyronine (Fig. 4-6), the highest values of the correlation coefficient were marked for subgroups of hyperthyroidism $(\mathrm{r}=0.59, \mathrm{P}<$ $0.01)$ and hypothyroidism $(\mathrm{r}=0.63, \mathrm{P}<0.05)$. Under conditions of psychoemotional stress in the subgroups of hyperthyroidism and hypothyroidism, the correlation coefficient increased $(\mathrm{r}=0.78, \mathrm{P}<0.001$ and $\mathrm{r}=0.75, \mathrm{P}<0.01$ correspondingly), the coefficient significance especially increased in the subgroup of hyperthyroidism.

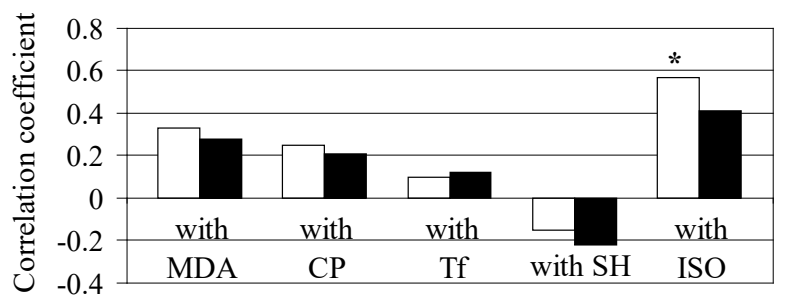

Fig. 1. Correlation coefficient indices between the level of thyroid-stimulating hormone (TSH) and the parameters of the oxidative/antioxidant system in the absence (white) and presence (black) of additional emotional load in persons from radiation contaminated territories (euthyroidism group, $\mathrm{n}=15$ ); * - reliability of the correlation coefficient, $\mathrm{P}<0.05$

The oxidative stress index positively correlated with TSH level in all subgroups under conditions of the absence of psychoemotional stress (euthyroidism: $\mathrm{r}=0.41, \mathrm{P}<0.05$; hyperthyroidism: $\mathrm{r}=0.40 ; \mathrm{P}<0.001$; hypothyroidism: $\mathrm{r}=0.48 ; \mathrm{P}<0.05$ ) with its presence, statistical significance of the correlation coefficients disappeared (Fig. 1-3). Also, oxida- tive stress index showed a negative correlation with $\mathrm{T}_{3}$ level in the hypothyroidism subgroup, the value of the correlation coefficient increased in conditions of emotional stress, but did not reach the level of statistical significance (Fig. 6).

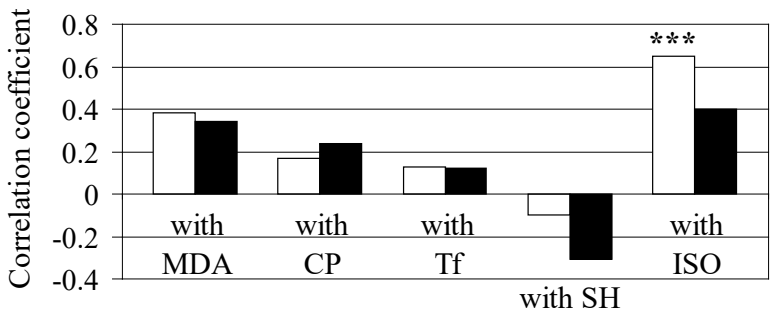

Fig. 2. Correlation coefficient indices between the level of thyroidstimulating hormone (TSH) and the parameters of the oxidative/antioxidant system in the absence (white) and presence (black) of additional emotional load in persons from radiation contaminated territories (hyperthyroidism group, $\mathrm{n}=24$ ); *** - reliability of the correlation coefficient, $\mathrm{P}<0.001$

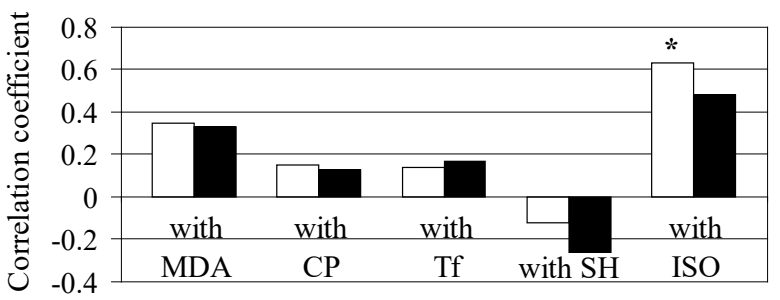

Fig. 3. Correlation coefficient indices between the level of thyroidstimulating hormone (TSH) and the parameters of the oxidative/antioxidant system in the absence (white) and presence (black) of additional emotional load in persons from radiation contaminated territories (hypothyroidism group, $\mathrm{n}=11$ ); ${ }^{*}$ - reliability of the correlation coefficient, $\mathrm{P}<0.05$

In the hyperthyroidism subgroup, the correlation coefficient changed its value from positive (before emotional load) to negative (during emotional stress). However, in neither case did this have statistical significance (Fig. 5). 


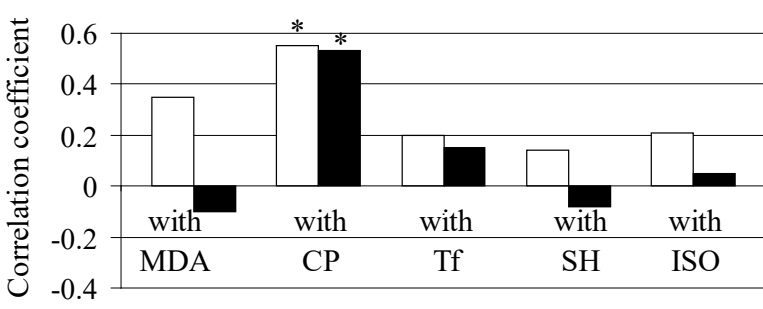

Fig. 4. Correlation coefficient indices between the level of serum total triiodothyronine $\left(\mathrm{T}_{3}\right)$ and the parameters of the oxidative/antioxidant system in the absence (white) and presence (black) of additional emotional load in persons from radiation contaminated territories (euthyroidism group, $\mathrm{n}=15$ ); ${ }^{*}$ - reliability of the correlation coefficient, $\mathrm{P}<0.05$

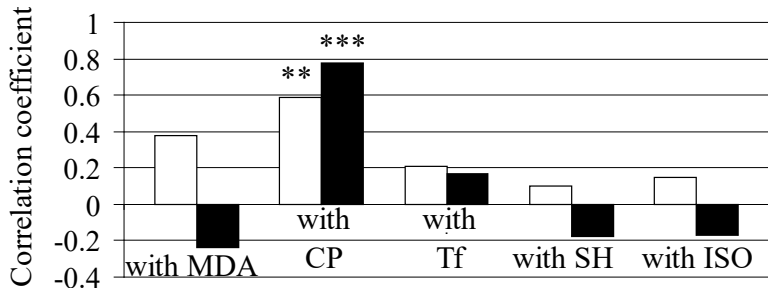

Fig. 5. Correlation coefficient indices between the level of serum total triiodothyronine $\left(\mathrm{T}_{3}\right)$ and the parameters of the oxidative/antioxidant system in the absence (white) and presence (black) of additional emotional load in persons from radiation contaminated territories (hyperthyroidism group, $\mathrm{n}=24) ;{ }^{* *}$ - reliability of the correlation coefficient, $\mathrm{P}<0.01 ; * * *-$ reliability of the correlation coefficient, $\mathrm{P}<0.001$

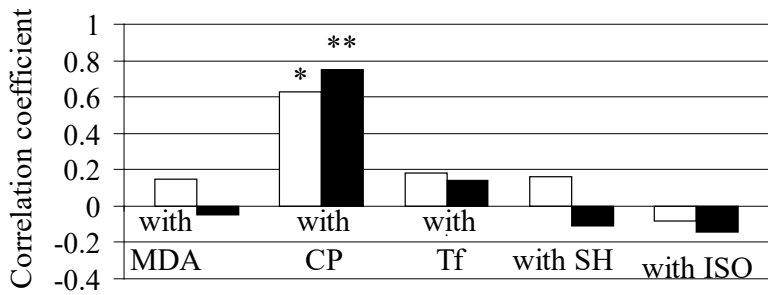

Fig. 6. Correlation coefficient indices between the level of serum total triiodothyronine $\left(\mathrm{T}_{3}\right)$ and the parameters of the oxidative/antioxidant system in the absence (white) and presence (black) of additional emotional load in persons from radiation contaminated territories (hypothyroidism group, $\mathrm{n}=11) ;{ }^{*}$ - reliability of the correlation coefficient,

$\mathrm{P}<0.05 ; * *-$ reliability of the correlation coefficient, $\mathrm{P}<0.01$

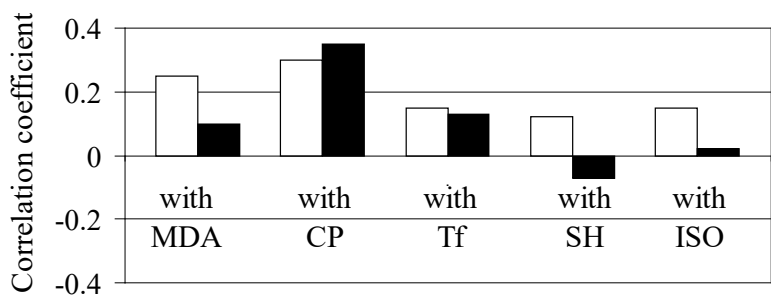

Fig. 7. Correlation coefficient indices between the level of serum total thyroxine $\left(\mathrm{T}_{4}\right)$ and the parameters of the oxidative/antioxidant system in the absence (white) and presence (black) of additional emotional load in persons from radiation contaminated territories (euthyroidism group, $\mathrm{n}=15$ )

\section{Discussion}

Recently, a significant body of evidence has been obtained on the importance of thyroid dysfunctions in the intensification of oxidative processes in the human body. Hypermetabolic state with hyperthyroidism is associated with oxidative tissue damage, in particular, due to the influence on mitochondria activity. Available data indicate that hyperthyroid tissues cause increased production of active forms of oxygen. Other biochemical processes, stimulated by hormones of the thyroid gland, increase the susceptibility of various tissues to oxidative influences, which increases the trauma or dysfunction caused by stress conditions (Venditti \& Di Meo, 2006). In the liver, oxidative stress caused by hormones of the thyroid gland leads to cell damage by increasing the permeability of the plasma membranes that modifies separate liver functions. In addition, $\mathrm{T}_{3}$-induced activity of a "metabolic (respiratory) explosion" in Kupffer cells may have harmful effects through the production of cytotoxins that are involved in the activation of inflammatory processes (Videla, 2000)

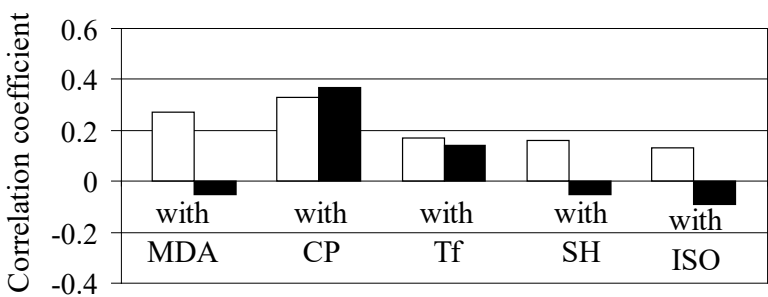

Fig. 8. Correlation coefficient indices between the level of serum total thyroxine $\left(\mathrm{T}_{4}\right)$ and the parameters of the oxidative/antioxidant system in the absence (white) and presence (black) of additional emotional load in persons from radiation contaminated territories (hyperthyroidism group, $n=24$ )

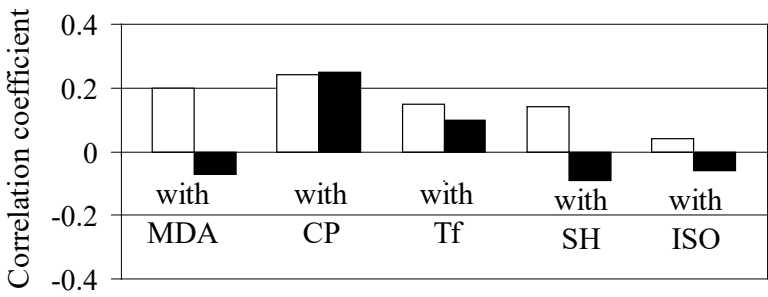

Fig. 9. Correlation coefficient indices between the level of serum total thyroxine $\left(\mathrm{T}_{4}\right)$ and the parameters of the oxidative/antioxidant system in the absence (white) and presence (black) of additional emotional load in persons from radiation contaminated territories (hypothyroidism group, $\mathrm{n}=11$ )

Oxidative stress is associated with both hyperthyroidism and hypothyroidism (Costantini et al., 1998; Yilmaz et al., 2003; Sarandöl et al., 2005; Villanueva et al., 2013), even in subclinical conditions. The growth of oxidative stress index is a concomitant phenomenon of a decrease in the conversion of thyroxine $\left(\mathrm{T}_{4}\right)$ to triiodothyronine $\left(\mathrm{T}_{3}\right)$, in particular with nonthyroid illness syndrome (NTIS). This suggests that oxidative stress in this case is not only a sign of the adaptation process but also connected with the state of hypothyroidism (Abilés et al., 2006; Mancini et al., 2016).

The increased index of oxidative stress, compared to control, was observed in our studies regardless of the thyroid status of examined patients aged 18-24 years in the experimental group. Theoretically, the highest values had to be expected in the subgroup with the signs of hyperthyroidism, which should lead to a general intensification of oxidative processes. According to the data, hyperthyroidism leads to the formation of oxidative stress and an oxidative-antioxidant imbalance in the body (Andryskowski \& Owczarek, 2007). Moreover, the level of TSH was atypically elevated in this subgroup. TSH excess directly induces oxidative stress (Dardano et al., 2006). Indeed, in many clinical cases (in particular, female sterility), TSH level growth is often accompanied by increase of malondialdehyde and ceruloplasmin concentration, which is a sign of oxidative stress (Al-Fahham, 2015; Hussein et al., 2017; Ramandeep et al., 2017). A positive correlation of TSH with lipid peroxidation was detected in children born in the families of Chornobyl accident liquidators (Borisko et al., 2008). 
However, in our studies, the average index of oxidative stress reached its highest value in the subgroup of hypothyroidism, at the same time it increased the most intensively in conditions of additional emotional stress; the difference with the subgroup of euthyroidism became statistically significant (Table 1). It was in the subgroup of hypothyroidism where the index of oxidative stress demonstrated a negative correlation with the level of $T_{3}$, which, however, had no statistical significance (Fig. 6). In the hyperthyroidism subgroup, OSI and $\mathrm{T}_{3}$ correlation coefficient also did not have statistical significance. However, it changed its value from positive (before emotional stress) to negative (during emotional stress) (Fig. 5). On the one hand, this indicated a certain protective role of triiodothyronine in the intensification of oxidative processes. On the other hand, taking into consideration the positive correlation between OSI and $\mathrm{T}_{3}$ in the euthyroidism subgroup (without any statistical significance), we can talk about the imbalance of the regulatory function of triiodothyronine in relation to the oxidative processes in individuals who have undergone prolonged exposure to small doses of radiation. Definitely, triiodothyronine in our studies did not act as a significant factor in stimulating oxidative processes by activating metabolic processes.

In general, available data for oxidative stress both in hypothyroiddism, and hyperthyroidism are quite controversial. There are not enough data for oxidative stress by subclinical hypothyroidism (Baskol et al., 2007; Torun et al., 2009; Haribabu et al., 2013). Logically, in hypothyroidism a low level of free radical formation is expected due to inhibition of metabolic processes and production of active forms of oxygen due to reduced levels of thyroid hormones (Erdamar et al., 2008). Low level of $\mathrm{T}_{3}$ can be considered as a compensatory antioxidant mechanism (Maia et al., 2005). Experimental data suggest that moderate hypothyroidism can promote longevity by reducing metabolism, oxidative stress and cellular aging (Garasto et al., 2017). However, some studies reported a high level of oxidative stress in patients not only with hyperthyroidism but also with hypothyroidism (Costantini et al., 1998; Yilmaz et al., 2003; Sarandöl et al., 2005; Villanueva et al., 2013), even in subclinical conditions. Experimental animal studies have shown that in the case of artificial stimulation of hypothyroidism, the level of lipid peroxidation is mostly determined by the age of the animals, what kind of tissues were analyzed and antioxidant enzymes activity (Yilmaz et al., 2003), the effect may also be influenced by the peculiarities of nutrition, in particular, the addition of vitamin E in a diet (Sarandöl et al., 2005).

Obviously, to understand the mechanisms of our results, we must analyze all the components of OSI.

Oxygen reactive forms may change the function and chemical structure of membrane lipids. The marker of lipid peroxidation during oxidative stress activation is malonic dialdehyde (Fernández-Sánchez et al., 2011; Leonard \& Maes, 2012). A high level of MDA, substantially correlated with $\mathrm{T}_{3}$ levels, was found in patients with schizophrenia (Akiibinu et al., 2012). Growth of MDA level against the background of $\mathrm{T}_{3}$ deficiency and antioxidant protection led to abortion (Ramandeep et al., 2017). There is evidence of a significant increase of MDA level in patients with hypothyroidism, which characterizes enhanced formation of active forms of oxygen and parallel disorder in the antioxidant system (Resch et al., 2002; Bhattacharya et al., 2014). It is noted that MDA was elevated in both patients with expressed and subclinical hypothyroidism compared with the control group, while the level of total antioxidant status (TAS) did not show significant differences between the groups (Baskol et al., 2007; Torun et al., 2009; Haribabu et al., 2013). A study conducted on patients with subclinical hypothyroidism, developed as a result of Hashimoto's thyroiditis, did not reveal any difference in levels of endogenous MDA between patients and the control group; however, the induction of MDA by prooxidant stimulants was significantly more intensive in patients with hypothyroidism (Öztürk et al., 2012). In patients with papillary cancer of the thyroid gland, MDA level in the prethyroidectomy period was significantly higher compared with controls, indicating that it was involved in the development of the pathological process (Kosova et al., 2007). During iodine therapy with radioactive iodine $\left({ }^{131} \mathrm{I}\right)$, MDA level increased even more, although, the therapy did not cause significant antioxidant status disorders (Vrndic et al., 2014). Treating patients with thyroid hormones reduced MDA levels (Baskol et al., 2007).
The absence of a significantly elevated MDA level in the examined subgroups of hyperthyroidism and hypothyroidism, subject to emotional load, can be explained by the fact of subclinical thyroid states. In addition, a significant variation in the MDA level was observed in the control group, as it can be seen from the standard error. In the experimental group, index variability was significantly lower, indicating the stabilization of oxidative processes at a certain level, obviously due to the adaptation to prolonged exposure of small doses of radiation. Under conditions of emotional stress, the level of malondialdehyde in persons from radiation-contaminated territories statistically significantly increased, in comparison with pre-exam values, regardless of thyroid status. At the same time, the index in both hyperthyroidism and in the hypothyroidism subgroups became significantly higher than control and euthyroidism subgroup index (Table 1). Taking into account the lack of statistically significant correlation between the level of MDA and the level of $\mathrm{T}_{3}$, which became the basis for division into subgroups, we draw the conclusion of the low contribution of triiodothyrodine in the implementation of detected changes in lipid peroxidation.

Perhaps the main role in the formation of malonic dialdehyde level in the experimental group was performed by specific lipid profile. Some authors believe that oxidative stress and MDA growth in hypothyroidism (both expressed and subclinical) are caused not by direct changes in thyroid status, but by changes in the lipid profile caused by thyroid dysfunction (Santi et al., 2012; Anjaneyulu et al., 2015; Cheserek et al., 2015). Prolonged availability of oxidative substrates (mainly low density lipoprotein cholesterol, LDL-C) in plasma increases their susceptibility to oxidative modification (Napoli et al., 1995). Probably, the primary effect is hyperlipidemia, caused by thyroid hormones, secondary - the use of excess lipids as substrates for $\mathrm{T}_{3}$ and accelerated consumption of the oxygen by hormones. This, in turn, leads to an increase in ROS, an increase in the consumption of cellular antioxidants and inactivation of antioxidant enzymes (Fernández et al., 2006; Venditti \& Di Meo, 2006). The value of $\mathrm{T}_{3}$ as an antioxidant in hypothyroid states is due to the promotion of ROS destruction by increasing the availability of antioxidants for cells and, correspondingly, protection of LDL-C from oxidation (Oziol et al., 2001). However, persistent hyperlipidemia can lead to antioxidant system overload and, subsequently, to a decrease in the level of antioxidant defense. As a consequence, with progressive hyperlipidemia, oxidative stress increases, which is observed in subclinical hypothyroidism (Yang et al., 2008; Cheserek et al., 2015). The effect is confirmed by a significant correlation between MDA and LDL-cholesterol levels, total cholesterol and triglycerides levels. Thus, activation of oxidative stress accompanied by an increase in MDA level, in subclinical hypothyroidism, is conditional not only to the reduction of antioxidant levels but also due to the altered lipid metabolism (Nanda et al., 2008; Torun et al., 2009; Haribabu et al., 2013).

Previously, we have shown that in hypothyroidism subgroups, in the absence of emotional stress, there is the highest level of low density lipoprotein cholesterol, the main substrate of lipid peroxidation. The statistical significance of the difference was observed not only in comparison with control, but also with subgroups of euthyroidism and hyperthyroidism. Under conditions of emotional stress, the level of LDL-C increased and was significantly higher than in the control and subgroup of euthyroidism. The level of LDL-C inversely correlated with the level of triiodothyronine; in the subgroup of hyperthyroidism, this correlation was positive. In all three subgroups, a statistically significant correlation between the level of LDL-C and the level of oxidative processes stimulator TSH (Sokolenko \& Sokolenko, 2017), was noted. Thus, thyroid status had a significant effect on the lipid metabolism of the examined patients, although its role was leveled to some extent in conditions of emotional stress. Hyperthyroidism (both expressed and subclinical) is often accompanied by a decrease in levels of total cholesterol, LDLcholesterol, HDL-cholesterol. These changes in the lipid profile are due to the regulatory influence of the thyroid hormones on the activity of some key lipoprotein metabolism enzymes, one of which is the stimulation of cholesterol synthesis. The levels of triglycerides remain unchanged. Hyperthyroidism leads to increased oxidation of LDL-C, which is closely related to the level of free $\mathrm{T}_{4}$. Normal cholesterol level is not always an accurate indicator of optimal thyroid function, but 
elevated cholesterol level is considered a sign of its dysfunction (Anjaneyulu et al., 2015).

In studies where the parameters of both hyperthyroid and hypothyroid patients were analyzed, it was demonstrated that hyperthyroidism showed the highest intensity of LDL-C peroxidation and a low level of antioxidants. Patients with hypothyroidism demonstrated intermediate values: LDL-C oxidation was significantly lower than with hyperthyroidism but higher than in the control group. With hyperthyroidism, but not in the other two groups, the LDL-C oxidation was significantly affected by the level of free thyroxine in the blood. However, in hypothyroidism the intensity of LDL-C oxidation significantly correlated with serum lipids level (Costantini et al., 1998).

Different authors report opposite changes in the intensity of lipid peroxidation caused by free oxygen radicals in both hyperthyroidism and hypothyroidism, but these data were obtained in experiments with animals. For humans, it is predominantly believed that lipid peroxidation increases with both states under different mechanisms (Dumitriu et al., 1988; Anjaneyulu et al., 2015).

We found a statistically significant correlation between the lowdensity lipoprotein cholesterol and MDA level $(r=0.59$ in the absence and $\mathrm{r}=0.68$ in the presence of additional emotional stress, $\mathrm{P}<0.001$ ) and the index of oxidative stress $(r=0.65$ in the absence and $r=0.75$ in the presence of additional emotional stress; $\mathrm{P}<0.001$ ). The growth of the importance of correlation dependence in terms of psychoemotional stress correlates with the literature data on increasing the value of corticoid hormones in the development of lipid metabolism disorders in conditions of chronic psychological stress, depression, low socio-economic status (Brotman et al., 2007; Engelking, 2010; Toth et al., 2014).

It is believed that reduced activity of antioxidants in the development of oxidative processes leads to dysfunctions of the thyroid gland (Karbownik \& Lewinski, 2003). Leading antioxidants are ceruloplasmin, transferrin (Memişoğulları \& Bakan, 2004; Somogyi et al., 2007) and sulfhydryl groups SH (Birben et al., 2012). The results obtained in our studies show that the formation of oxidative stress and its intensification in conditions of psychoemotional stress in people with different thyroid status was determined precisely by antioxidant factors. In particular, in the absence of statistically significant differences in MDA level between subgroups and control (before emotional load), in the hypothyroidism subgroup the level of ceruloplasmin was statistically significantly reduced compared to control. In the hyperthyroidism subgroup the level of ceruloplasmin significantly decreased during an additional emotional load against the background of $\mathrm{T}_{3}$ decrease (Table 1). This indicates the important protective role of triiodothyronine in relation to this antioxidant factor. The effect was confirmed by the correlation analysis of $\mathrm{T}_{3}$ and $\mathrm{CP}$ : a statistically significant correlation, in particular in the subgroups of hyperthyroidism and hypothyroidism; an increase in significance in conditions of psychoemotional stress, especially in the subgroup of hyperthyroidism (Fig. 5). Ceruloplasmin is $\alpha_{2}$ globulin, which contains about $95 \%$ of the total amount of copper in serum. The primary physiological role of $\mathrm{CP}$ is to provide redox reactions of plasma. It can function as an oxidant or antioxidant depending on the certain factors. Ceruloplasmin is important for controlling the membrane lipids oxidation and is a major agent of protecting against the harmful effects of active forms of oxygen in cells (Ha et al., 1996; Kim et al., 1998; Das \& Chainy, 2004).

The literature contains some data that differs from the results we have obtained. In particular, it was reported that hyperthyroidism, due to $\mathrm{T}_{3}$ growth practically does not affect the level of transferrin and ceruloplasmin (Graninger et al., 1986). However, most studies of the recent years prove that thyroid hormones stimulate synthesis and also export of synthesized in the serum ceruloplasmin, thereby regulating the level of copper in the blood (Mittag et al., 2012; Hybsier et al., 2015). Consequently, patients with hypothyroidism have significantly lower ceruloplasmin level, against MDA growth, than the control. As a consequence, even after 6 months treatment, the activation of lipid peroxidation remains, which is probably caused by a low level of CP in serum (Bhattacharya et al., 2014). Significant correlations between ceruloplasmin level and thyroid status was found in patients with chronic kidney disease (Zainal, 2016).
Taking into account the parallel decrease (compared to control) in level of sulfhydryl compounds in the experimental group (before and during emotional stress) and the fact that in both hyperthyroidism and hypothyroidism subgroups the rate was significantly lower than in the euthyroidism subgroup, it is obvious that the following complex of antioxidant status has determined the specifics of the oxidative processes in the examined group.

According to the literature, under normal conditions, the protective effect of thyroid hormones on oxidative stress can be explained by the modulation of the antioxidant system and its maintenance on the quality level (Fernández et al., 2006; Joshi et al., 2011). Thyroid hormones activate the cyclicity of ATP, which enhances oxidative phosphorylation and reduces ROS formation; increase the production of reducing substances that promote ROS removal (Moustafa et al., 2009). Investigation of the system of antioxidant defense under hyperthyroid conditions show quite contradictory results (Venditti \& Di Meo, 2006). There are reports that the influence of hyperthyroidism on the activity of antioxidant enzymes, including copper-containing, depends on the tissue, with $\mathrm{T}_{3}$ and $\mathrm{T}_{4}$ having differentiated effects (Huh et al., 1998). The same contradictions are observed with respect to hypothyroid cases. Some sources indicate that the total antioxidant status with expressed hypothyroidism, subclinical hypothyroidism and in control is usually similar (Torun et al., 2009). In others, low levels of total antioxidant capacity are noted in patients with hypothyroidism (Mancini et al., 2010).

There is an assumption that oxidative stress and the reduction of antioxidant defense in hypothyroidism are the result of biochemical processes in the physiological adaptation to the condition. Thyroid hormones in humans take part in the suppression of the toxic effects of oxidative stress (Baskol et al., 2007). It is logical to think that oxidative stress is associated with both hyperthyroidism and hypothyroidism, but the mechanisms by which it is generated in these clinical states are differrent: hyperthyroidism is associated with increased production of active forms of oxygen, hypothyroidism - with the low availability of antioxidants (Resch et al., 2002).

In general, antioxidant depletion, observed in people with hypothyroidism, may reflect an increase in the production of free radicals in the chain of electron transport on the internal membrane of mitochondria. The increase in free radicals is not compensated, as expected, due to a decrease in the number of antioxidants, in particular ceruloplasmin. Thus, the cells of the patients are probably damaged in a result of prolonged oxidative stress, which greatly exceeds the ability of the organs of the patients to synthesize antioxidant molecules or to receive them from extracellular sources (Joshi et al., 2011). It is believed that the prooxidant environment in hypothyroid patients forms the preconditions for atherosclerosis development (Baskol et al., 2007). Taking into consideration that hypothyroidism is closely related to hypertension by means of sympathetic and adrenal activation (Fommei \& Iervasi, 2002), the presence of vegetative-vascular dystonia syndrome in a significant number of examined patients in the experimental group with signs of hypothyroidism is logical, as reported earlier (Sokolenko, 2016; Sokolenko \& Sokolenko, 2017).

An important role in the development of certain pathologies of the thyroid gland belongs to the factors that cause the activation of active oxygen production and, at the same time, are characterized as destabilizers of endocrine functions: heavy metals, ionizing radiation, certain chemicals. Their action is realized by a wide spectrum of moleculartoxic mechanisms (Colucci et al., 2015). Probably, prolonged residence in radiation-contaminated territories influenced the formation of interrelationships between the thyroid and oxidative-antioxidant status of the examined students from the experimental group.

Recently it has been considered necessary to study in detail the changes in human health in the context of the chronic effects of low doses of radiation. The results of such studies are important and can be used for proper radiation protection and for determining the safety requirements for living in conditions of high radiation background, especially with regard to ongoing discussions about "dose-response" curves describing radiation-related effects and the severity of radiation damage (Ryan, 2012; Einor et al., 2016). Ionizing radiation can also affect proteins, nucleic acids and complex lipids as a result of formation of active 
forms of oxygen by water radiolysis or changes in mitochondrial functions (Kam \& Banati, 2013). Different publications describe the bond between LDIR and the formation of reactive oxidative factors (Azzam et al., 2012; Smith et al., 2012). Oxidative damage can be one of the mechanisms that underlie various harmful effects of radiation, is a manifestation of its catalytic activity and is realized depending on the ratio of increased ROS concentrations and reduced activity of antioxidant enzymes against the background of genetic damage, concomitant diseases, inflammation, and food deficiency (Spitz et al., 2004; Halliwell \& Gutteridge, 2007; Einor et al., 2016).

It should be considered that in all students examined from the experimental group, in addition to the OSI growth, one more typical symptom of a stressful situation was observed - an increased cortisol level in blood serum (Table 1), and in the conditions of an additional emotional load, both indicators increased. Previously, we showed a statistically significant correlation between the level of cortisol and the index of oxidative stress in the examined group (Sokolenko \& Sokolenko, 2016a). This confirms that realization of adaptive response to chronic exposure, as a stress factor, in inhabitants of the territory of enhanced radioecological control is realized in various ways, both physiological and biochemical mechanisms are involved. There are reports on the probability of involvement of emotional factors in the process (Contis \& Foley, 2015), and, as we have shown, short-term additional emotional stress increases already existing radiation-induced stress. A similar phenomenon is manifested during physical load, but in this case, the intensity of physical activity is significant (Filaire et al., 2009; Ardern et al., 2016; Sokolenko \& Sokolenko, 2016). The state of the immune system should also be taken into account: previous publications reported a significant correlation of oxidative stress and lipid metabolism with the level and phagocytic activity of neutrophils (Sokolenko, 2016; Sokolenko \& Sokolenko, 2017; Sokolenko et al., 2018). Neutrophils produce active forms of oxygen, which contributes to the development of inflammation (Fernández-Sánchez et al., 2011; Lutai et al., 2016). The functional polarization of phagocytes (neutrophils and monocytes), characterized by the ratio of the production of reactive forms of oxygen and phagocytic activity, depends on many factors, in particular, the period of the day, physical activity, the state of lipid metabolism (Skivka et al., 2015a, 2015b; Rudyk et al., 2016, 2018). There are data on dependence of functional status of neutrophils on thyroid status parameters (Mezosi et al., 2005; Marino et al., 2006; Mathison, 2006; Kurjane et al., 2012).

The analysis of involvement into the adaptive response formation (at the level of the oxidative antioxidant system) of the thyroid status demonstrated some imbalance of the interactions between thyroid hormones and the index of oxidative stress. In addition, the inhibition of the ability of thyroid hormones to maintain an adequate antioxidant state is shown. Taking into account the earlier data published, one can say that the leading factors associated with the formation of oxidative stress among inhabitants of radiation-contaminated territories aged 18-24 without severe pathologies was the state of lipid metabolism and hyperproduction of cortisol (Sokolenko \& Sokolenko, 2017; Sokolenko et al., 2018).

\section{Conclusions}

Individuals aged 18-24 who had lived for a long time in radiationcontaminated areas of Cherkasy region, show a variation of the interrelation between thyroid hormones and oxidative stress index, which can be characterized as a moderate imbalance of homeostatic mechanisms. A certain role in the activation of lipid peroxidation, manifested by MDA level growth, was played by a thyroid-stimulating hormone. The contribution of triiodothyrodine to detected changes of MDA level is low. The participation of the thyroid status in supporting redox homeostasis was mainly realized by the influence on the system of antioxidants, in particular, ceruloplasmin level. This was confirmed by its positive correlation with the level of triiodothyronine. However, the ability of thyroid hormones to maintain a proper antioxidant status in people who have undergone prolonged exposure to small doses of radiation is suppressed. The level of cortisol and lipid status could influence the implementation of the interrelation between the thyroid status and the oxidative-antioxidant system of the examined students. The unbalanced relationship between thyroid hormones and oxidative stress indicators was manifested most strongly under conditions of additional emotional stress.

\section{References}

Abilés, J., de la Cruz, A. P., Castaño, J., Rodríguez-Elvira, M., Aguayo, E., Moreno-Torres, R., Llopis, J., Aranda, P., Arguelles, S., Ayala, A., de la Quintana, A. M., \& Planells, E. M. (2006). Oxidative stress is increased in critically ill patients according to antioxidant vitamins intake, independent of severity: A cohort study. Critical Care, 10(5), R146.

Abou-El-Ardat, K., Monsieurs, P., Anastasov, N., Atkinson, M., Derradji, H., De Meyer, T., Bekaert, S., Van Criekinge, W., \& Baatout, S. (2012). Low dose irradiation of thyroid cells reveals a unique transcriptomic and epigenetic signature in RET/PTC-positive cells. Mutation Research/Fundamental and Molecular Mechanisms of Mutagenesis, 731(1), 27-40.

Akiibinu, M. O., Ogundahunsi, O. A., \& Ogunyemi, E. O. (2012). Inter-relationship of plasma markers of oxidative stress and thyroid hormones in schizophrenics. BMC Research Notes, 5(1), 169-174.

Al-Fahham, A. A. (2015). Correlation between oxidative stress and thyroid hormone levels in infertile women. International Journal of Scientific and Research Publications, 5(12), 128-131.

Andryskowski, G., \& Owczarek, T. (2007). The evaluation of selected oxidative stress parameters in patients with hyperthyroidism. Polskie Archiwum Medycyny Wewnetrznej, 117(7), 285-289.

Anjaneyulu, O., Pottennagari, S., \& Dammalapati, P. K. (2015). Lipoproteins and lipid peroxidation in thyroid disorders. IOSR Journal of Biotechnology and Biochemistry, 1(2), 32-37.

Ardern, C. L., Glasgow, P., Schneiders, A., Witvrouw, E., Clarsen, B., Cools, A., Gojanovic, B., Griffin, S., Khan K. M., Moksnes, H., Mutch, S. A., Phillips, N., Reurink, G., Sadler, R., Silbernagel, K. G., Thorborg, K., Wangensteen, A., Wilk, K. E., \& Bizzini, M. (2016). 2016 Consensus statement on return to sport from the First World Congress in Sports Physical Therapy, Bern. British Journal of Sports Medicine, 50(14), 853-864.

Azzam, E. I., Jay-Gerin, J. P., \& Pain, D. (2012). Ionizing radiation-induced metabolic oxidative stress and prolonged cell injury. Cancer Letters, 327(1-2), 48-60.

Baser, H., Can, U., Baser, S., Yerlikaya, F. H., Aslan, U., \& Hidayetoglu, B. T. (2015). Assesment of oxidative status and its association with thyroid autoantibodies in patients with euthyroid autoimmune thyroiditis. Endocrine, 48(3), 916-923.

Baskol, G., Atmaca, H., Tanriverdi, F., Baskol, M., Kocer, D., \& Bayram, F. (2007). Oxidative stress and enzymatic antioxidant status in patients with hypothyroidism before and after treatment. Experimental and Clinical Endocrinology and Diabetes, 115(8), 522-526.

Bhattacharya, A., Saha, R., Mondal, T., Choudhuri, S., \& Gupta, S. (2014). Ceruloplasmin and serum MDA levels in hypothyroid patients. International Journal of Biomedical And Advance Research, 5(8), 369-372.

Birben, E., Sahiner, U. M., Sackesen, C., Erzurum, S., \& Kalayci, O. (2012). Oxidative stress and antioxidant defense. World Allergy Organization Journal, 5(1), 9-19.

Borisko, G. A., Kashkalda, D. A., Kalmykova, N. V., \& Cherevatova, S. K. (2008). Osobennosti vzaimootnosheniy pokazateley gormonalnoy regulyatsii i obmennykh protsessov u detey iz semey radiatsionnogo riska [Peculiarities of the mutual relation between the indices of hormonal regulation and metabolism of the children from the families of radiation risk]. Visnyk Kharkivskoho Natsionalnoho Universytetu imeni V. N. Karazina. Seriia: Biolohiia, 814, 58 (in Russian).

Brotman, D. J., Golden, S. H., \& Wittstein, I. S. (2007). The cardiovascular toll of stress. The Lancet, 370(9592), 1089-1100.

Campos, C., \& Casado, Á. (2015). Oxidative stress, thyroid dysfunction and down syndrome. The Indian Journal of Medical Research, 142(2), 113-119.

Cardis, E., \& Hatch, M. (2011). The Chernobyl accident - an epidemiological perspective. Clinical Oncology, 23(4), 251-260.

Cheserek, M. J., Wu, G. R., Ntazinda, A., Shi, Y. H., Shen, L. Y., \& Le, G. W. (2015). Association between thyroid hormones, lipids and oxidative stress markers in subclinical hypothyroidism. Journal of Medical Biochemistry, 34(3), 323-331.

Colucci, R., Dragoni, F., \& Moretti, S. (2015). Oxidative stress and immune system in vitiligo and thyroid diseases. Oxidative medicine and cellular longevity, 2015, 631927.

Combs Jr, G. F., \& Combs, S. B. (1986). The role of selenium in nutrition. Orlando, Academic Press.

Contis, G., \& Foley Jr, T. P. (2015). Depression, suicide ideation, and thyroid tumors among Ukrainian adolescents exposed as children to Chernobyl radiation. Journal of Clinical Medicine Research, 7(5), 332. 
Costantini, F., Pierdomenico, S. D., Cesare, D. D., De Remigis, P., Bucciarelli, T., Bittolo-Bon, G., Gazzlato, G., Nubile, G., Guagnano, M., Sensi, S., \& Cuccurullo, F. (1998). Effect of thyroid function on LDL oxidation. Arteriosclerosis, Thrombosis, and Vascular Biology, 18(5), 732-737.

Dardano, A., Ghiadoni, L., Plantinga, Y., Caraccio, N., Bemi, A., Duranti, E., Taddey, S., Ferrannini, E., Salvetti, A., \& Monzani, F. (2006). Recombinant human thyrotropin reduces endothelium-dependent vasodilation in patients monitored for differentiated thyroid carcinoma. The Journal of Clinical Endocrinology and Metabolism, 91(10), 4175-4178.

Das, K., \& Chainy, G. B. N. (2004). Thyroid hormone influences antioxidant defense system in adult rat brain. Neurochemical Research, 29(9), 1755-1766.

De Vito, P., Balducci, V., Leone, S., Percario, Z., Mangino, G., Davis, P. J., Davis, F. B., Affabris, E., Luly, P., Pedersen, J. Z., \& Incerpi, S. (2012). Nongenomic effects of thyroid hormones on the immune system cells: New targets, old players. Steroids, 77(10), 988-995.

Dostert, P., Benedetti, M. S., \& Frigerio, E. (1991). Effect of L-dopa, oxyferriscorbone and ferrous iron on in vivo lipid peroxidation. Journal of Neural Transmission, 84(1-2), 119-128.

Dumitriu, L., Bartoc, R., Ursu, H., Purice, M., \& Ionescu, V. (1988). Significance of high levels of serum malonyl dialdehyde (MDA) and ceruloplasmin (CP) in hyper-and hypothyroidism. Endocrinologie, 26(1), 35-38.

Einor, D., Bonisoli-Alquati, A., Costantini, D., Mousseau, T. A., \& Møller, A. P. (2016). Ionizing radiation, antioxidant response and oxidative damage: A metaanalysis. Science of the Total Environment, 548, 463-471.

Engelking, L. R. (2010). Textbook of veterinary physiological chemistry. Academic Press.

Erdamar, H., Demirci, H., Yaman, H., Erbil, M. K., Yakar, T., Sancak, B., Elbeg, S., Biberglu, G., \& Yetkin, I. (2008). The effect of hypothyroidism, hyperthyroidism, and their treatment on parameters of oxidative stress and antioxidant status. Clinical Chemistry and Laboratory Medicine, 46(7), 1004-1010.

Fernández, V., Tapia, G., Varela, P., Romanque, P., Cartier-Ugarte, D., \& Videla, L. A. (2006). Thyroid hormone-induced oxidative stress in rodents and humans: A comparative view and relation to redox regulation of gene expression. Comparative Biochemistry and Physiology. Part C: Toxicology and Pharmacology, 142(3-4), 231-239.

Fernández-Sánchez, A., Madrigal-Santillán, E., Bautista, M., Esquivel-Soto, J., Morales-González, Á., Esquivel-Chirino, C., Durante-Montiel, I., SánchezRivera, G., Valadez-Vega, C., \& Morales-González, J. A. (2011). Inflammation, oxidative stress, and obesity. International Journal of Molecular Sciences, 12(5), 3117-3132.

Filaire, E., Alix, D., Ferrand, C., \& Verger, M. (2009). Psychophysiological stress in tennis players during the first single match of a tournament. Psychoneuroendocrinology, 34(1), 150-157.

Fommei, E., \& Iervasi, G. (2002). The role of thyroid hormone in blood pressure homeostasis: Evidence from short-term hypothyroidism in humans. The Journal of Clinical Endocrinology and Metabolism, 87(5), 1996-2000.

Fushiki, S. (2013). Radiation hazards in children-lessons from Chernobyl, Three Mile Island and Fukushima. Brain and Development, 35(3), 220-227.

Garasto, S., Montesanto, A., Corsonello, A., Lattanzio, F., Fusco, S., Passarino, G., Giarritta, P., \& Corica, F. (2017). Thyroid hormones in extreme longevity. Mechanisms of Ageing and Development, 165, 98-106.

Graninger, W., Pirich, K. R., Speiser, W., Deutsch, E., \& Waldhäusl, W. K. (1986). Effect of thyroid hormones on plasma protein concentrations in man. The Journal of Clinical Endocrinology and Metabolism, 63(2), 407-411.

Ha, T. K. K., Sattar, N., Talwar, D., Cooney, J., Simpson, K., O'reilly, D. S. J., \& Lean, M. E. J. (1996). Abnormal antioxidant vitamin and carotenoid status in chronic renal failure. QJM: An International Journal of Medicine, 89(10), 765-770.

Halliwell, B., \& Gutteridge, J. M. (2015). Free radicals in biology and medicine. Oxford University Press, Oxford.

Haribabu, A., Reddy, V. S., Pallavi, C., Bitla, A. R., Sachan, A., Pullaiah, P., Suresh, V., Rao, S., \& Suchitra, M. M. (2013). Evaluation of protein oxidation and its association with lipid peroxidation and thyrotropin levels in overt and subclinical hypothyroidism. Endocrine, 44(1), 152-157.

Huh, K., Kwon, T. H., Kim, J. S., \& Park, J. M. (1998). Role of the hepatic xanthine oxidase in thyroid dysfunction: Effect of thyroid hormones in oxidative stress in rat liver. Archives of Pharmacal Research, 21(3), 236-240.

Hussein, R. A. M., Al-Salih, R. M., \& Ali, S. A. R. (2017). A study of prolactin, thyroid stimulating hormones, malondialdehyde and ceruloplasmin levels in infertile women, in Thi-Qar Governorate/Iraq. Thi-Qar Medical Journal, 14(2), 14-21.

Hybsier, S., Höfig, C., Mittag, J., Brabant, G., \& Schomburg, L. (2015). Control of serum copper $(\mathrm{Cu})$ and selenium (Se) status by thyroid hormones. Experimental and Clinical Endocrinology and Diabetes, 123(3), 12-18.

Boice, J. D. Jr. (2017). Chapter 3 - From Chernobyl to Fukushima and Beyond A focus on thyroid cancer. Thyroid cancer and nuclear accidents. Long-term aftereffects of Chernobyl and Fukushima. Pp. 21-32.
Joshi, V. R., Mallick, A. K., Goud, M. B., Maradi, R., Reddy, M. G., Tey, R., \& Shorey, G. (2011). Effect of serum copper concentration and ceruloplasmin on lipid parameters leading to increased propensity to cardiovascular risk. Research Journal of Pharmaceutical, Biological and chemical Science, 2(2), 558-563.

Kam, W. W. Y., \& Banati, R. B. (2013). Effects of ionizing radiation on mitochondria. Free Radical Biology and Medicine, 65, 607-619.

Kannisto, K., Rehnmark, S., Slätis, K., Webb, P., Larsson, L., Gafvels, M., Eggertsen, G. \& Parini, P. (2014). The thyroid receptor $\beta$ modulator GC-1 reduces atherosclerosis in ApoE deficient mice. Atherosclerosis, 237(2), 544-554.

Karbownik, M., \& Lewinski, A. (2003). The role of oxidative stress in physiological and pathological processes in the thyroid gland; possible involvement in pineal-thyroid interactions. Neuro Endocrinology Letters, 24(5), 293-303.

Kim, I. G., Park, S. Y., Kim, K. C., \& Yum, J. J. (1998). Thiol-linked peroxidase activity of human ceruloplasmin. FEBS Letters, 431(3), 473-475.

Korol, L. V., \& Myhal, L. A. (2012). Method of integral evaluation of oxidantantioxidant balance in blood serum [Sposib intehralnoi otsinky oksydantnoantyoksydantnoho balansu u syrovatsi krovi]. Patent № 102192 UA, CIP G01N 33/48 (2006.01). No a201205647. 08.05.2012. Publ. 10.06.2013, Bul. No 11. (in Ukrainian).

Kosova, F., Çetin, B., Akıncı, M., Aslan, S., Arı, Z., Sepici, A., Altan, N., \& Çetin, A. (2007). Advanced oxidation protein products, ferrous oxidation in xylenol orange, and malondialdehyde levels in thyroid cancer. Annals of Surgical Oncology, 14(9), 2616-2620.

Kurjane, N., Bruvere, R., Shitova, O., Romanova, T., Jaunalksne, I., Kirschfink, M., \& Sochnevs, A. (2001). Analysis of the immune status in Latvian Chernobyl clean-up workers with nononcological thyroid diseases. Scandinavian Journal of Immunology, 54(5), 528-533.

Leonard, B., \& Maes, M. (2012). Mechanistic explanations how cell-mediated immune activation, inflammation and oxidative and nitrosative stress pathways and their sequels and concomitants play a role in the pathophysiology of unipolar depression. Neuroscience and Biobehavioral Reviews, 36(2), $764-785$.

Lindemann, J. A. L., Angajala, A., Engler, D. A., Webb, P., \& Ayers, S. D. (2014). Thyroid hormone induction of human cholesterol 7 alpha-hydroxylase (Cyp7a1) in vitro. Molecular and Cellular Endocrinology, 388(1), 32-40.

Loseva, O., Shubbar, E., Haghdoost, S., Evers, B., Helleday, T., \& Harms-Ringdahl, M. (2014). Chronic low dose rate ionizing radiation exposure induces premature senescence in human fibroblasts that correlates with up regulation of proteins involved in protection against oxidative stress. Proteomes, 2(3), 341-362.

Lutai, Y. M., Parkhomeko, O. M., Ryzhkova, N. O., Havrylenko, T. I., Irkin, O. I., Kozhukhov, S. M., Stepura, A. O., \& Bilyi, D. O. (2016). Vplyv terapii vnutrishnovennym inhibitorom 5-lipoksyhenazy kvertsetynom na funktsiiu endoteliiu, vyrazhenist systemnoho zapalennia ta prooksydantnoho stresu pry hostromu infarkti miokarda z elevatsiieiu ST [Effects of Intravenous 5lipoxygenase inhibitor quercetin therapy on endothelial function, severity of systemic inflammation and oxidative stress in acute myocardial infarction with elevation of ST]. Medytsyna Nevidkladnykh Staniv, 1, 111-119 (in Ukrainian).

Maia, A. L., Kim, B. W., Huang, S. A., Harney, J. W., \& Larsen, P. R. (2005). Type 2 iodothyronine deiodinase is the major source of plasma $T_{3}$ in euthyroid humans. The Journal of Clinical Investigation, 115(9), 2524-2533.

Mancini, A., Di Segni, C., Raimondo, S., Olivieri, G., Silvestrini, A., Meucci, E., \& Currò, D. (2016). Thyroid hormones, oxidative stress, and inflammation. Mediators of Inflammation, 2016, 6757154.

Mancini, A., Festa, R., Donna, V. D., Leone, E., Littarru, G. P., Silvestrini, A., Meucci, E., \& Pontecorvi, A. (2010). Hormones and antioxidant systems: Role of pituitary and pituitary-dependent axes. Journal of Endocrinological Investigation, 33(6), 422-433.

Marino, F., Guasti, L., Cosentino, M., De Piazza, D., Simoni, C., Piantanida, E., Cimpanelli, M., Klersy, C., Bartalena, L., Venco, A., \& Lecchini, S. (2006). Thyroid hormone regulation of cell migration and oxidative metabolism in polymorphonuclear leukocytes: Clinical evidence in thyroidectomized subjects on thyroxine replacement therapy. Life Sciences, 78, 1071-1077.

Mathison, R. (2006). Modulation of neutrophil function by hormones. Current Immunology Reviews, 2(3), 247-259.

MemişoğullariR., \& Bakan, E. (2004). Levels of ceruloplasmin, transferrin, and lipid peroxidation in the serum of patients with Type 2 diabetes mellitus. Journal of Diabetes and its Complications, 18(4), 193-197.

Mezosi, E., Szabo, J., Nagy, E. V., Borbely, A., Varga, E., Paragh, G., \& Varga, Z. (2005). Nongenomic effect of thyroid hormone on free-radical production in human polymorphonuclear leukocytes. Journal of Endocrinology, 185(1), 121-129.

Mittag, J., Behrends, T., Nordström, K., Anselmo, J., Vennström, B., \& Schomburg, L. (2012). Serum copper as a novel biomarker for resistance to thyroid hormone. Biochemical Journal, 443(1), 103-109. 
Moustafa, A. H. A., Ali, E. M., Mohamed, T. M., \& Abdou, H. I. (2009). Oxidative stress and thyroid hormones in patients with liver diseases. European Journal of Internal Medicine, 20(7), 703-708

Mustafina, S. V., Rimar, O. D., Simonova, G. I., Ragino, Y. I., Kuznetsov, S. S. Scherbakova, L. V., \& Malyutina, S. K. (2010). Funkcional'noe sostojanie shhitovidnoj zhelezy i lipidnyj profil' krovi [Functional state of thyroid gland and lipid blood profile]. Ateroskleroz, 6(2), 15-19 (in Russian)

Nanda, N., Bobby, Z., \& Hamide, A. (2008). Oxidative stress and protein glycation in primary hypothyroidism. Male/female difference. Clinical and Experimental Medicine, 8(2), 101-108.

Napoli, C., Postiglione, A., Triggiani, M., Corso, G., Palumbo, G., Carbone, V., Ruocco, A., Ambrosio, G., Montefusco, S., Malorni, A., Condorelli, M., \& Chiariello, M. (1995). Oxidative structural modifications of low density lipoprotein in homozygous familial hypercholesterolemia. Atherosclerosis, $118(2), 259-273$.

Nylund, R., Lemola, E., Hartwig, S., Lehr, S., Acheva, A., Jahns, J., Hildebrandt, G., \& Lindholm, C. (2014). Profiling of low molecular weight proteins in plasma from locally irradiated individuals. Journal of Radiation Research, 55(4), 674-682.

Oziol, L., Faure, P., Vergely, C., Rochette, L., Artur, Y., Chomard, P., \& Chomard, P. (2001). In vitro free radical scavenging capacity of thyroid hormones and structural analogues. Journal of Endocrinology, 170(1), 197-206.

Öztürk, Ü., Vural, P., Özderya, A., Karadağ, B., Doğru-Abbasoğlu, S., \& Uysal, M. (2012). Oxidative stress parameters in serum and low density lipoproteins of Hashimoto's thyroiditis patients with subclinical and overt hypothyroidism. International Immunopharmacology, 14(4), 349-352.

Popovych, I. L., Fliunt, I. S., Alieksieiev, O. I., Baryliak, L. H., \& Bilas, V. R (2003). Sanogenetychni zasady reabilitacii' na kurorti Truskavec' urologichnyh hvoryh chornobyl's'kogo kontyngentu [Sanogenetic principles of rehabilitation of urological patients of Chornobyl contingent at Truskavets resort]. Komp'juterpres, Kyiv (in Ukrainian).

Ramandeep, K., Kapil, G., \& Harkiran, K. (2017). Correlation of enhanced oxidative stress with altered thyroid profile: Probable role in spontaneous abortion International Journal of Applied and Basic Medical Research, 7(1), 20-25.

Resch, U., Helsel, G., Tatzber, F., \& Sinzinger, H. (2002). Antioxidant status in thyroid dysfunction. Clinical Chemistry and Laboratory Medicine, 40(11), $1132-1134$

Rudyk, M. P., Pozur, V. V., Voieikova, D. O., Hurmach, Y. V., Khranovska, N. M., Skachkova, O. V., Svyatetska, V. M., Fedorchuk, O. G., Skivka, L. M., Berehova, T. V., \& Ostapchenko, L. I. (2018). Sex-based differences in phagocyte metabolic profile in rats with monosodium glutamate-induced obesity. Scientific Reports, 8(1), 5419

Rudyk, M., Fedorchuk, O., Susak, Y., Nowicky, Y., \& Skivka, L. (2016). Introduction of antineoplastic drug NSC631570 in an inpatient and outpatient setting: Comparative evaluation of biological effects. Asian Journal of Pharmaceutical Sciences, 11(2), 308-317.

Rumiantsev, P. O., Saenko, V. A., \& Dedov, I. I. (2017). Chapter 10 - Influence of radiation exposure and ultrasound screening on the clinical behavior of papillary thyroid carcinoma in young patients. Thyroid cancer and nuclear accidents. Long-term aftereffects of Chernobyl and Fukushima. Pp. 97-107.

Ryan, J. L. (2012). Ionizing radiation: The good, the bad, and the ugly. Journal of Investigative Dermatology, 132(3), 985-993.

Santi, A., Duarte, M. M., de Menezes, C. C., \& Loro, V. L. (2012). Association of lipids with oxidative stress biomarkers in subclinical hypothyroidism. International Journal of Endocrinology, 2012, 856359.

Sarandöl, E., Taş, S., Dirican, M., \& Serdar, Z. (2005). Oxidative stress and serum paraoxonase activity in experimental hypothyroidism: Effect of vitamin $\mathrm{E}$ supplementation. Cell Biochemistry and Function: Cellular Biochemistry and its Modulation by Active Agents or Disease, 23(1), 1-8.

Sinha, R. A., Singh, B. K., \& Yen, P. M. (2014). Thyroid hormone regulation of hepatic lipid and carbohydrate metabolism. Trends in Endocrinology and Metabolism, 25(10), 538-545

Skivka, L. M., Fedorchuk, O. G., Khranovska, N. M., Rudyk, M. P., \& Opeida I. V. (2015). Diurnal variation in functional reserve and metabolic polarization of circulating monocytes in healthy men. European Journal of Clinical Investigation, 45, 49-50.

Skivka, L. M., Fedorchuk, O. G., Susak, Y. M., Susak, M. Y., Malanchuk, O. M. Rudyk, M. P., \& Nowicky, Y. W. (2015a). Physical activity interferes with the immunomodulatory effect of the antineoplastic drug NSC631570. Current Pharmaceutical Biotechnology, 16(1), 49-59.
Smith, J. T., Willey, N. J., \& Hancock, J. T. (2012). Low dose ionizing radiation produces too few reactive oxygen species to directly affect antioxidant concentrations in cells. Biology Letters, 8(4), 594-597.

Sokolenko, V. L. (2016). Pokaznyky kholesterynu ta imunnoyi systemy u osib z oznakamy veheto-sudynnoyi dystoniyi, shcho prozhyvaly na terytoriyakh, zabrudnenykh radionuklidamy [Cholesterol rate and immune system indices in people with symptoms of vegetative-vascular dystonia, who lived in the territories contaminated with radionuclides]. World of Medicine and Biology, 2, 86-90 (in Ukrainian).

Sokolenko, V. L., \& Sokolenko, S. V. (2015). Aktyvnist radionuklidiv i realizatsiia funktsii imunnoi systemy u meshkantsiv radiatsiino zabrudnenykh terytorii [Radionuclide activity and the immune system functioning in residents of radiation contaminated areas]. Regulatory Mechanisms in Biosystems, 6(2), 93-96 (in Ukrainian).

Sokolenko, V. L., \& Sokolenko, S. V. (2016). Vplyv pomimykh fizychnykh navantazhen na pokaznyky imunnoi systemy u meshkantsiv radiatsiino zabrudnenykh terytorij [Influence of moderate physical load on parameters of the immune system among residents of contaminated areas]. Regulatory Mechanisms in Biosystems, 7(1), 48-52.

Sokolenko, V. L., \& Sokolenko, S. V. (2016a). Osoblyvosti okysnoi ta antyoksydantnoi system u meshkantsiv terytorii, zabrudnenykh radionuklidamy [Specifics of oxidant and antioxidant systems in residents of the territories contaminated with radionuclides]. Visnyk Problem Biolohii i Medytsyny, 4(1), 176-180 (in Ukrainian).

Sokolenko, V. L., \& Sokolenko, S. V. (2017). Vzaiemozviazok lipidnoho obminu ta tyreoidnoho statusu za prolonhovanoho vplyvu malykh doz radiatsii [The interaction between lipid exchange and thyroid status in the conditions of prolonged influence of small doses of radiation]. Regulatory Mechanisms in Biosystems, 8(2), 231-238 (in Ukrainian).

Sokolenko, V. L., Sokolenko, S. V., Sheiko, V. I., \& Kovalenko, O. V. (2018). Interconnection of the immune system and the intensity of the oxidative processes under conditions of prolonged exposure to small doses of radiation. Regulatory Mechanisms in Biosystems, 9(2), 167-176.

Somogyi, A., Rosta, K., Pusztai, P., Tulassay, Z., \& Nagy, G. (2007). Antioxidant measurements. Physiological Measurement, 28(4), R41.

Spitz, D. R., Azzam, E. I., Li, J. J., \& Gius, D. (2004). Metabolic oxidation/reduction reactions and cellular responses to ionizing radiation: A unifying concept in stress response biology. Cancer and Metastasis Reviews, 23(3-4), 311-322.

Stone, W. L., \& Dratz, E. A. (1982). Selenium and non-selenium glutathione peroxidase activities in selected ocular and non-ocular rat tissues. Experimental Eye Research, 35(5), 405-412.

Takamura, N., Orita, M., Saenko, V., Yamashita, S., Nagataki, S., \& Demidchik, Y. (2016). Radiation and risk of thyroid cancer: Fukushima and Chernobyl. The Lancet Diabetes and Endocrinology, 4(8), 647.

Torun, A. N., Kulaksizoglu, S., Kulaksizoglu, M., Pamuk, B. O., Isbilen, E., \& Tutuncu, N. B. (2009). Serum total antioxidant status and lipid peroxidation marker malondialdehyde levels in overt and subclinical hypothyroidism. Clinical Endocrinology, 70(3), 469-474.

Toth, P. P., Grabner, M., Punekar, R. S., Quimbo, R. A., Cziraky, M. J., Jacobson, T. A. (2014). Cardiovascular risk in patients achieving low-density lipoprotein cholesterol and particle targets. Atherosclerosis, 235(2), 585-591.

Venditti, P., \& Di Meo, S. (2006). Thyroid hormone-induced oxidative stress. Cellular and Molecular Life Sciences, 63(4), 414-434.

Videla, L. A. (2000). Energy metabolism, thyroid calorigenesis, and oxidative stress: Functional and cytotoxic consequences. Redox Report, 5(5), 265-275.

Villanueva, I., Alva-Sanchez, C., \& Pacheco-Rosado, J. (2013). The role of thyroid hormones as inductors of oxidative stress and neurodegeneration. Oxidative Medicine and Cellular Longevity, 2013, 218145.

Vrndic, O. B., Radivojevic, S. D., Jovanovic, M. D., Djukic, S. M., Teodorovic L. C. M., \& Simonovic, S. T. Z. (2014). Oxidative stress in patients with differentiated thyroid cancer: Early effects of radioiodine therapy. Indian Journal of Biochemistry and Biophysics, 51(3), 223-229.

Yang, R. L., Shi, Y. H., Hao, G., Li, W., \& Le, G. W. (2008). Increasing oxidative stress with progressive hyperlipidemia in human: Relation between malondialdehyde and atherogenic index. Journal of Clinical Biochemistry and Nutrition, 43(3), 154-158.

Yilmaz, S., Ozan, S., Benzer, F., \& Canatan, H. (2003). Oxidative damage and antioxidant enzyme activities in experimental hypothyroidism. Cell Biochemistry and Function, 21(4), 325-330.

Zainal, I. G. (2016). Relationship between thyroid function, cystatin C and differrent oxidative stress in Iraqi patients with chronic kidney disease. Medical Journal of Babylon, 13(2), 337-346. 